\title{
Biological activities and chemical composition of a cytotoxin of Klebsiella oxytoca
}

\author{
JunZaburo Minami, ${ }^{1}$ Seiki Saito, ${ }^{2}$ Takashi Yoshida, ${ }^{3}$ TakaAki Uemura ${ }^{4}$ and \\ AKINOBU OKABE ${ }^{1 *}$ \\ ${ }^{1}$ Department of Microbiology, Kagawa Medical School, 1750-1 Ikenobe, Miki-cho, Kita-gun, Kagawa 761-07, Japan \\ ${ }^{2}$ Department of Applied Chemistry, Faculty of Engineering, Okayama University, 3-1-1 Tsushima, Okayama 700, Japan \\ ${ }^{3}$ Faculty of Pharmaceutical Sciences, Okayama University, 1-1-1 Tsushima, Okayama 700, Japan \\ ${ }^{4}$ Kanonji Institute, The Research Foundation for Microbial Diseases of Osaka University, Kanonji, Kagawa 768, Japan
}

(Received 6 May 1992; accepted 18 June 1992)

\begin{abstract}
A low-molecular-mass cytotoxin produced by Klebsiella oxytoca isolated previously from patients with antibioticassociated haemorrhagic enterocolitis was purified, and its biological and chemical properties were elucidated. The toxin inhibited the syntheses of DNA and RNA by HEp-2 cells dose-dependently, whereas protein synthesis was only slightly inhibited, as measured by the incorporation of radioactive precursors. When synchronously cultured HEp-2 cells were examined in the presence of cytotoxin, inhibition of DNA synthesis occurred promptly within $\mathbf{5}$ h, but cell-rounding, the earliest visible morphological change, was not observed until $6 \mathrm{~h}$ after exposure. The intracellular levels of ATP decreased with an approximately similar time course. These results suggest that cytotoxicity toward HEp-2 cells is primarily due to the inhibitory effect of the cytotoxin on nucleic acid synthesis, possibly on DNA synthesis. Cell rounding and cell death were induced even in the absence of the cytotoxin after incubation with the cytotoxin for $6 \mathrm{~h}$. The cytotoxin was heat-labile, cytotoxic activity decreasing to $50 \%$ of the initial level on heating at $70{ }^{\circ} \mathrm{C}$ for $20 \mathrm{~min}$. Plasmids were extracted from three strains of $K$. oxytoca producing the cytotoxin and analysed by agarose gel electrophoresis. Two strains possessed plasmids of different sizes, but one strain possessed no plasmid, indicating that the cytotoxin is probably chromosomally encoded. Analysis by NMR and FAB-mass-spectrometry revealed that the molecular mass of the cytotoxin should be 217.1062 Da (exact mass), its molecular formula being $\mathrm{C}_{8} \mathrm{H}_{15} \mathrm{O}_{4} \mathrm{~N}_{3}$.
\end{abstract}

\section{Introduction}

Klebsiella oxytoca isolated from patients with antibioticassociated haemorrhagic enterocolitis have been shown to produce a cytotoxin (Minami et al., 1989). This cytotoxin exerts a cytotoxic effect, e.g. cell-rounding followed by cell death, on many tissue culture cells, such as HEp-2, CHO, HeLa and Vero cells, and hence can be regarded as a factor responsible for the enterocolitis caused by this organism (Minami et al., 1989). The most outstanding feature of the cytotoxin is its low molecular mass. Cytotoxins have been isolated from many bacteria, such as Shigella sp. (O’Brien \& Holmes, 1987), Escherichia coli (O'Brien \& Holmes, 1987), Clostridium difficile (Donta \& Shaffer, 1980, Lima et al., 1988), Campylobacter jejuni (Guerrant et al., 1987) and Salmonella sp. (Ketyi et al., 1979; O'Brien et al., 1982; Baloda et al.,

\footnotetext{
* Author for correspondence. Fax 81878987109.
}

1983; Koo \& Peterson, 1983; Ashkenazi et al., 1988), but they are protein or proteinaceous toxins with high molecular masses (more than $10 \mathrm{kDa}$ ) in contrast to the $K$. oxytoca cytotoxin (less than $1 \mathrm{kDa}$ ).

Recently, a cytotoxin of low molecular mass from Bordetella pertussis was purified and characterized (Rosenthal et al., 1987; Cookson et al., 1989). The $B$. pertussis tracheal cytotoxin is a disaccharide tetrapeptide subunit of peptidoglycan, molecular mass approx. $1 \mathrm{kDa}$, causing a ciliated-cell-specific respiratory tract pathology. This cytotoxin, together with that of $K$. oxytoca, suggests that cytotoxins of low molecular mass can be produced by some bacteria and can contribute to the virulence of highly or even potentially pathogenic bacteria. Elucidation of the molecular nature of the $K$. oxytoca cytotoxin, and the mechanism underlying cellrounding and cell death induced by the cytotoxin would provide useful information for understanding the pathogenicity of this bacterium and related Enterobacteria- 
ceae. In this study we examine the effects of the cytotoxin on macromolecular synthesis by HEp- 2 cells and present evidence that it preferentially inhibits nucleic acid synthesis.

In a previous paper (Minami et al., 1989), we described a procedure for the purification of the cytotoxin, consisting of gel filtration on Sephadex G-25 and Bio-gel $\mathbf{P} 2$, and reversed-phase HPLC. In this study, the cytotoxin has been further purified by extraction with chloroform after the above procedure, and has been analysed by NMR and FAB-mass spectrometry to determine its chemical composition.

\section{Methods}

Organisms. Three clinically isolated strains of $K$. oxytoca (OK-1, KA1 and KA-2) and the type strain of K.oxytoca, ATCC 13182, were used in this study. The three strains were isolated from patients with haemorrhagic diarrhoea after the administration of penicillin derivatives as chemotherapy for an upper respiratory infection, and were characterized previously (Minami et al., 1989).

Purification of $K$. oxytoca cytotoxin. K. oxytoca $\mathrm{OK}-1$ was grown in Trypto-Soya broth (Nissui Pharmaceutical, Tokyo) at $37^{\circ} \mathrm{C}$ for $12 \mathrm{~h}$, and the $K$. oxytoca cytotoxin was purified from the culture supernatant by gel filtration on Sephadex G-25 and Bio-Gel P-2, and reversed-phase HPLC, as described previously (Minami et al., 1989).

Measurement of ATP in HEp-2 cells. A 24-well plate was used to culture HEp-2 cells. Each well was seeded with $1 \times 10^{5} \mathrm{HEp}-2$ cells. The cells were cultured in $1 \mathrm{ml}$ of Eagle's minimum essential medium with Earle's salts, $100 \mu \mathrm{g}$ streptomycin $\mathrm{ml}^{-1}$ and $100 \mathrm{U}$ penicillin $\mathrm{ml}^{-1}$ (MEM medium) supplemented with $10 \%(\mathrm{v} / \mathrm{v})$ foetal bovine serum in the presence of $5 \%(\mathrm{v} / \mathrm{v}) \mathrm{CO}_{2}$ at $37^{\circ} \mathrm{C}$ for $24 \mathrm{~h}$ to establish monolayers. The medium was replaced by fresh MEM medium supplemented with $5 \%(\mathrm{v} / \mathrm{v})$ foetal bovine serum. After incubation at $37^{\circ} \mathrm{C}$ for $1 \mathrm{~h}$, the cytotoxin was added to a final concentration of $8 \mu \mathrm{g} \mathrm{ml}^{-1}$. ATP in HEp2 cells was extracted from monolayered cells in each well with $200 \mu$ $0.5 \mathrm{M}$-perchloric acid. The extract was neutralized with $5 \mathrm{M}$-potassium hydroxide and the precipitate removed by centrifugation. The extracted ATP was determined by HPLC on an anion exchange column $(4.6 \times 250 \mathrm{~mm})$ of DEAE-2SW (Toyo Soda Manufacturing, Tokyo) equilibrated with $360 \mathrm{mM}$-sodium phosphate buffer, $\mathrm{pH} 6.0$, as described by Watanabe et al. (1985). After solubilization of HEp-2 cells with $1 \mathrm{M}-\mathrm{NaOH}$, protein was measured by the Lowry method with bovine serum albumin as standard.

Macromolecular synthesis. The effects of $K$. oxytoca cytotoxin on macromolecular synthesis were examined using HEp-2 cells. The synthesis of DNA, RNA and protein by HEp-2 cells in a 96-well plate were monitored by measuring the incorporation into the TCAprecipitable fraction of $\left[{ }^{3} \mathrm{H}\right]$ thymidine, $\left[{ }^{3} \mathrm{H}\right]$ uridine and $\left[{ }^{3} \mathrm{H}\right]$ leucine, respectively. HEp-2 cells were maintained in Eagle's minimum essential medium containing Earle's salts supplemented with $10 \%(\mathrm{v} / \mathrm{v})$ foetal bovine serum, $100 \mu \mathrm{g}$ streptomycin $\mathrm{ml}^{-1}$ and $100 \mathrm{U}$ penicillin $\mathrm{ml}^{-1}$ (basal medium). Each well was seeded with $1 \times 10^{4} \mathrm{HEp}-2$ cells, followed by incubation in the presence of $5 \%(\mathrm{v} / \mathrm{v}) \mathrm{CO}_{2}$ at $37^{\circ} \mathrm{C}$ for $24 \mathrm{~h}$ to establish monolayers. Nonsynchronous cultures of HEp- 2 cells were used for the experiments on protein and RNA syntheses. Cultures synchronized at the $S$ phase were used for the experiment on DNA synthesis. Synchronization was performed as follows. Monolayers of cells in the wells of a microculture plate were incubated in the basal medium supplemented with $2.5 \mathrm{~mm}$-thymidine for $24 \mathrm{~h}$. The medium was then removed and the plate was washed once with Dulbecco's phosphate-buffered saline (PBS). After the addition of fresh basal medium without thymidine, the plate was incubated for $10 \mathrm{~h}$, followed by the addition of hydroxyurea to a final concentration of $1 \mathrm{~mm}$. After incubation for 14 to $16 \mathrm{~h}$, the medium was removed. The plate was washed three times with PBS, and then $0 \cdot 2 \mathrm{ml}$ of incorporation medium [Eagle's minimum essential medium containing Earle's salts supplemented with $5 \%(\mathrm{v} / \mathrm{v})$ foetal bovine serum $100 \mu \mathrm{g}$ streptomycin $\mathrm{ml}^{-1}$ and $100 \mathrm{U}$ penicillin $\mathrm{ml}^{-1}$ ] was added. Leucine-deficient incorporation medium was used for the experiment on protein synthesis. Prewarmed washing solutions and media were used throughout these procedures.

Experiments on DNA and protein syntheses were done as follows. The basal medium in each well with a monolayer of cells was replaced with $0.2 \mathrm{ml}$ incorporation medium, followed by the addition of $50 \mu \mathrm{l}$ of medium containing cytotoxin and radioactive precursors to initiate cell labelling. One microcurie of [methyl- ${ }^{3} \mathrm{H}$ ]thymidine $\left(25 \mathrm{Ci} \mathrm{mmol}{ }^{-1}\right.$; $925 \mathrm{GBq} \mathrm{mmol}^{-1}$; Amersham) and $0.5 \mu \mathrm{Ci}$ of L-[4,5- $\left.{ }^{3} \mathrm{H}\right]$ leucine $(120$ $190 \mathrm{Ci} \mathrm{mmol}^{-1}$; 4.44-7.03 $\mathrm{TBq} \mathrm{mmol}^{-1}$; Amersham) were added to each well to monitor the syntheses of DNA and protein, respectively, and the plate incubated at $37^{\circ} \mathrm{C}$. At the indicated times, the medium was removed and the plate washed three times with PBS. Cells were solubilized by the addition of $37 \mu 10.5 \mathrm{M}-\mathrm{KOH}$ to a well, and incubation on a vibrating platform at room temperature for $30 \mathrm{~min}$. Bovine serum albumin, $7.5 \mu \mathrm{l}$ of a $0.15 \%(\mathrm{w} / \mathrm{v})$ solution, was added as a carrier protein and the solubilized cells were then precipitated with $270 \mu \mathrm{l}$ cold $10 \%$ (w/v) TCA. TCA-precipitable materials were collected at $4{ }^{\circ} \mathrm{C}$ on a glass fibre filter using a Titertek cell harvester (Flow Laboratories) and then washed with cold $5 \%(\mathrm{w} / \mathrm{v})$ TCA. The precipitate on the filter disk was treated with NCS solubilizer (Amersham). Radioactivity was measured with a liquid scintillation counter, using ACS II scintillation cocktail (Amersham).

For the experiment on RNA synthesis, cells were treated as described above, except that $1 \mu \mathrm{Ci}$ per well of $\left[5-{ }^{3} \mathrm{H}\right]$ uridine $(29 \mathrm{Ci}$ $\mathrm{mmol}^{-1} ; 1 \cdot 1 \mathrm{TBq} \mathrm{mmol}{ }^{-1}$; Amersham) was used and the labelled cells were solubilized in a different manner. After the indicated incubation times, the cells were washed, and detached by trypsinization $[0.25 \%$ (w/v) trypsin and $0.02 \%$ EDTA at $37^{\circ} \mathrm{C}$ for $5 \mathrm{~min}$ ], collected on a glass fibre filter and washed with PBS. After precipitation and washing with cold $5 \%(w / v)$ TCA, the filter was treated with NCS solubilizer and its radioactivity was measured as described above.

Assay for cytotoxic activity. HEp-2 cells were monolayered and cultured in a 96-well plate, and then the cytotoxic activity $\left(\mathrm{CD}_{50}\right)$ of $K$. oxytoca cytotoxin was measured using HEp-2 cells as described in the previous paper (Minami et al., 1989). $\mathrm{CD}_{50}$ was expressed as the dry weight of the cytotoxin (in $250 \mu \mathrm{l}$ medium) required to cause the rounding of $50 \%$ of the HEp- 2 cells after incubation at $37^{\circ} \mathrm{C}$ for $48 \mathrm{~h}$. The $\mathrm{CD}_{50}$ of the purified cytotoxin was $0 \cdot 15 \mu \mathrm{g}$ per well (Minami et al., 1989).

Plasmid analysis. Plasmids were extracted from $K$. oxytoca strains by the method of Kado \& Liu (1981) and then electrophoresed on a $0.7 \%$ agarose gel at $50 \mathrm{~V}$ with the electrophoresis buffer, i.e. $2 \mathrm{mM}$-EDTA and $40 \mathrm{~mm}$-Tris acetate, $\mathrm{pH} 7.9$. After electrophoresis, the gel was stained with ethidium bromide $\left(0.5 \mu \mathrm{g} \mathrm{ml}^{-1}\right)$ and then photographed under a UV illuminator.

Chemical analysis. ${ }^{1} \mathrm{H}$ - and ${ }^{13} \mathrm{C}-\mathrm{NMR}$ spectra were recorded on a Varian VXR-500 instrument (500 MHz for ${ }^{1} \mathrm{H}-\mathrm{NMR}$ and $126 \mathrm{MHz}$ for ${ }^{13} \mathrm{C}-\mathrm{NMR}$ ). ${ }^{31} \mathrm{P}-\mathrm{NMR}$ spectra were determined on a Varian VXR-200 instrument. Deuteriochloroform was used as a solvent. Chloroform soluble cytotoxin (several $\mathrm{mg}$ ) was purified on a short-path column packed with $2 \mathrm{~g}$ silica gel (Merck 60-7734) using chloroform ethanol $(24: 1)$ as the eluent. Fractions containing the cytotoxin, as judged by analytical TLC, were concentrated under reduced pressure at room 

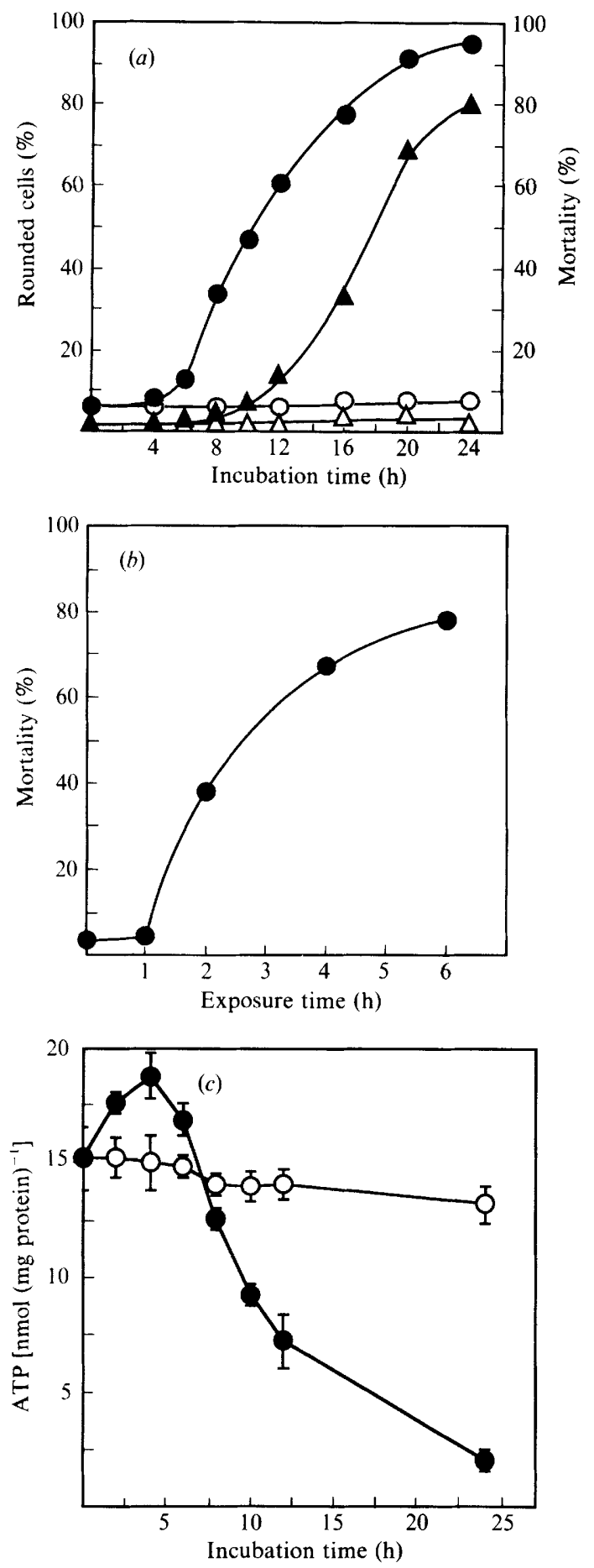

Fig. 1. (a) Time courses of cytotoxin-induced cell-rounding, and mortality of HEp-2 cells. HEp-2 cells were cultured in $250 \mu \mathrm{l} \mathrm{MEM}$ medium supplemented with $5 \%(\mathrm{v} / \mathrm{v})$ foetal bovine serum in the presence and absence of the cytotoxin in a 96-well plate. Mortality was determined by trypan blue exclusion. Numbers of rounded cells and trypan-blue-uptaking cells were determined under a microscope. A total of 600 cells were examined. Data are means of three determinations. $O$ Rounded cells in the absence of cytotoxin; rounded cells in the presence of $2 \mu \mathrm{g}\left(13.3 \mathrm{CD}_{50}\right)$ cytotoxin per well; $\triangle$, mortality in the absence of cytotoxin; $\Delta$, mortality in the presence of $2 \mu \mathrm{g}$ cytotoxin per well. (b) Mortality of HEp-2 cells exposed to $K$. oxytoca cytotoxin for temperature to give an almost colorless viscous oil, which was dissolved in deuteriochloroform $(0.7 \mathrm{ml})$ for NMR analysis. All NMR measurements were carried out in the standard manner at $20^{\circ} \mathrm{C}$ (probe temperature). FAB mass spectra were obtained on a VG Analytical VG-70SE double focusing mass spectrometer, employing 3-nitrobenzyl alcohol matrix, in the standard manner. Analytical TLC was performed on pre-coated Merck silica gel $60 \mathrm{~F}_{254}(0.25 \mathrm{~mm}$ thickness $)$.

\section{Results}

\section{Effects of $K$. oxytoca cytotoxin on HEp-2 cells}

A characteristic feature of the cytotoxicity exerted by the $K$. oxytoca cytotoxin is cell-rounding. Fig. $1(a)$ shows the time course of cell-rounding and mortality of HEp- 2 cells during incubation in the presence of the cytotoxin $(2 \mu \mathrm{g}$ per well). In the early incubation period, up to $6 \mathrm{~h}$, cellrounding occurred only slightly (less than $13 \%$ ), but thereafter rounded cells increased in number, accounting for more than $90 \%$ of the total cells after $24 \mathrm{~h}$ incubation. On the other hand, cell death was observed in a significant number of cells only after $8 \mathrm{~h}$ incubation and proceeded similarly to cell-rounding except for a time lag of $2-3 \mathrm{~h}$. These results indicate that the cell-rounding does not result from cell death and that heterogeneity exists in susceptibility of individual HEp-2 cells to the cytotoxin.

An irreversible change might have occurred in an early incubation period when no morphological change of the HEp-2 cells was observed. We examined irreversibility of the cytotoxicity to HEp- 2 cells. At various time intervals after addition of the cytotoxin, the cells were washed and cultured in fresh medium without the cytotoxin. As shown in Fig. $1(b)$ the cytotoxic effect was reversible when cells were exposed to the cytotoxin only for $1 \mathrm{~h}$. However, an irreversible effect was exerted on a substantial fraction of the cells when they were exposed for more than $2 \mathrm{~h}$. Mortality increased proportionally to length of exposure time, which may also reflect the

various periods of time. HEp-2 cells were cultured in $250 \mu \mathrm{l} \mathrm{MEM}$ medium supplemented with $5 \%(\mathrm{v} / \mathrm{v})$ foetal bovine serum in a 98 -well plate. At various times during incubation in the presence of $2 \mu \mathrm{g}$ cytotoxin per well, the medium was removed and HEp-2 cells were washed. The cells were cultured in fresh medium without the cytotoxin for $24 \mathrm{~h}$. Mortality of HEp- 2 cells was determined by counting cells taking up trypan blue under a microscope. A total of 600 cells were examined. Data are means of three determinations. (c) Changes in ATP levels in HEp-2 cells during incubation with $K$. oxytoca cytotoxin. HEp- 2 cells were cultured in $1 \mathrm{ml}$ MEM medium supplemented with $5 \%(v / v)$ foetal bovine serum in the presence and absence of the cytotoxin $\left(8 \mu \mathrm{g} \mathrm{ml}^{-1}\right)$ in a 24 -well plate. Data are means of three determinations \pm standard deviation. ATP levels in HEp-2 cells were measured as described in Methods. O, ATP in HEp-2 cells cultured in the absence of cytotoxin; 1 ATP in HEp- 2 cells cultured in the presence of cytotoxin. 
heterogeneity of HEp-2 cells in susceptibility to the cytotoxin.

Cell-rounding seems to be a critical morphological change leading to cell death. However, it did not occur so rapidly and cells were irreversibly affected before it. This suggests that specific changes in cell metabolism might induce the early period of incubation. To examine the effects on cellular energy metabolism, intracellular ATP levels were determined during the course of incubation with the cytotoxin (Fig. 1c). The level of ATP increased slightly in the early period, but started to decrease at $6 \mathrm{~h}$ incubation. It decreased to $15 \%$ of the ATP level in a control culture after $24 \mathrm{~h}$. Its decrease is similar to appearance of round cells both in initiation time and rate. Therefore, the decrease in the ATP level could be associated with the morphological change but could not be a primary effect of the cytotoxin.

\section{Inhibition of macromolecular synthesis}

The effects of the cytotoxin on macromolecular synthesis by HEp- 2 cells were examined. Monolayers of nonsynchronized HEp-2 cells in a 96-well plate were used to assay the incorporation of $\left[{ }^{3} \mathrm{H}\right]$ uridine and $\left[{ }^{3} \mathrm{H}\right]$ leucine, while cells synchronized at the $\mathrm{S}$ phase were used to assay the incorporation of $\left[{ }^{3} \mathrm{H}\right]$ thymidine with efficient labelling of DNA on the microculture plate. Fig. 2 shows the dose-dependent inhibition of macromolecular synthesis in HEp-2 cells by the cytotoxin. Protein synthesis remained virtually unaffected with concentrations of up to as much as $5 \mu \mathrm{g}$ per well and was inhibited only slightly with $10 \mu \mathrm{g}$ per well. In contrast, both DNA and RNA syntheses were significantly inhibited with $5 \mu \mathrm{g}$ or less per well. The inhibition of DNA synthesis was especially marked, the inhibitory effect of $1 \mu \mathrm{g}$ of the cytotoxin on DNA synthesis being comparable to that of $10 \mu \mathrm{g}$ of the cytotoxin on RNA synthesis. This suggests that the cytotoxin primarily inhibits DNA synthesis, and the inhibitions of RNA and protein syntheses are secondary effects.

Time course of DNA synthesis inhibition by the cytotoxin

Synchronized HEp-2 cells at the S phase in a microculture plate were incubated in the presence and absence of $2 \mu \mathrm{g}$ cytotoxin per well, examining inhibition of DNA synthesis and cell-rounding at various times. No significant difference in the time course of cell-rounding was observed between synchronous and nonsynchronous HEp-2 cells (data not shown). The incorporation of $\left[{ }^{3} \mathrm{H}\right]$ thymidine in the presence of the cytotoxin was inhibited to approximately $45 \%$ of the level in the absence of the cytotoxin as early as $1 \mathrm{~h}$ after incubation was started (Fig. 3). The inhibition continued during

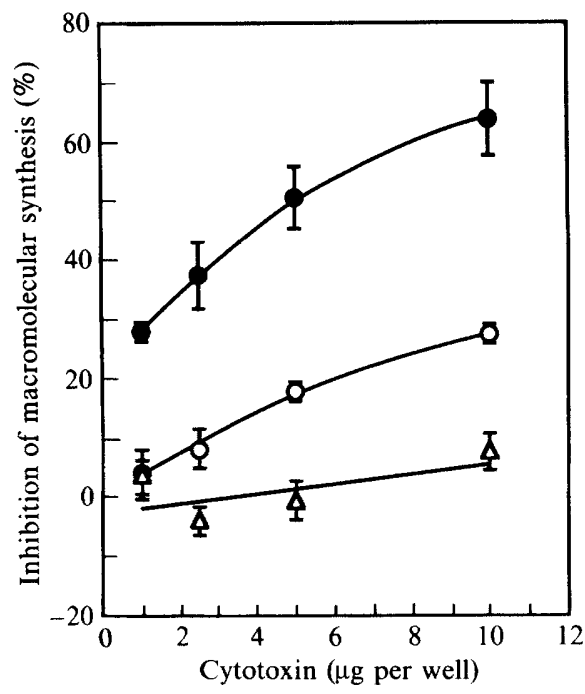

Fig. 2. Dose-response effects of $K$. oxytoca cytotoxin on DNA, RNA and protein syntheses by HEp- 2 cells. Percent inhibition was calculated from the radioactivities incorporated into TCA-precipitable materials after incubation in the presence and absence of the cytotoxin for $3 \mathrm{~h}$. Data are means of three determinations $\pm \mathrm{SD}$, calculated from the radioactivities of,$\left[{ }^{3} \mathrm{H}\right]$ thymidine; $O,\left[{ }^{3} \mathrm{H}\right]$ uridine; and $\triangle,\left[{ }^{3} \mathrm{H}\right]$ leucine incorporated. Radioactivities of $\left[{ }^{3} \mathrm{H}\right]$ thymidine, $\left[{ }^{3} \mathrm{H}\right]$ uridine and $\left[{ }^{3} \mathbf{H}\right]$ leucine incorporated in the absence of the cytotoxin $\left(4.53 \pm 0.29 \times 10^{4}\right.$ c.p.m., $2.17 \pm 0.20 \times 10^{4}$ c.p.m. and $9.32 \pm 1.30$ $\times 10^{4}$ c.p.m., respectively) were used as control values to calculate percent inhibition.

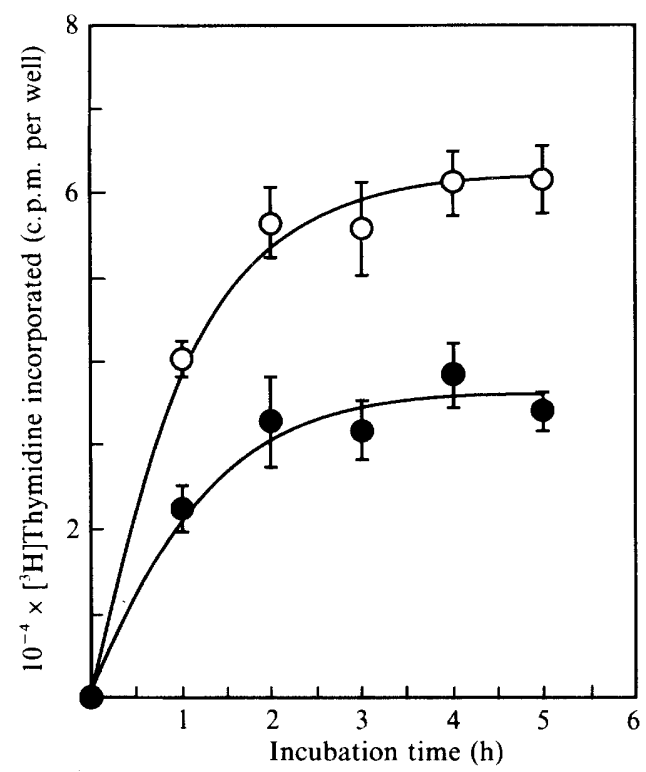

Fig. 3. The effect of $K$. oxytoca cytotoxin on $\left[{ }^{3} \mathrm{H}\right]$ thymidine incorporation into TCA-precipitable materials in HEp-2 cells. Cytotoxin $(2 \mu \mathrm{g})$ was added to each well. Radioactivities incorporated in the presence $(O)$ and absence of the cytotoxin $(O)$ were determined as described in the text. Data are presented as the means for three determinations \pm standard deviation. 
subsequent incubation, the incorporation gradually decreasing and finally stopping, indicating that the cytotoxin exerts its inhibitory effect on DNA synthesis within $1 \mathrm{~h}$. On the other hand, cell-rounding was significantly observed only after $6 \mathrm{~h}$ incubation, as with nonsynchronous cells (Fig. 1a).

\section{Analysis of $K$. oxytoca plasmids}

Many virulence factors of bacteria are encoded by plasmids. Therefore, we extracted and analysed plasmids from the three clinically isolated strains of $K$. oxytoca produced the cytotoxin. Fig. 4 shows the plasmid profiles for strains OK-1, KA-1 and KA-2 on agarose gel. Strain OK- 1 carried $34 \mathrm{~kb}$ and $3.5 \mathrm{~kb}$ plasmids, and strain KA2 carried a $3.5 \mathrm{~kb}$ plasmid, whilst strain KA-1 carried no plasmids. Therefore, it can be concluded that the cytotoxin is likely not encoded by plasmids, but is probably chromosomally determined.

\section{Heat stability of the purified cytotoxin}

There was a possibility that the cytotoxicity might be due to the presence of a trace amount of heat-stable endotoxin in the purified cytotoxin. In order to rule out this possibility, the sensitivity of the purified cytotoxin to heat was examined. The cytotoxic activity decreased to $50 \%$ of the initial level on heating at $70{ }^{\circ} \mathrm{C}$ for $20 \mathrm{~min}$. Heating at $90^{\circ} \mathrm{C}$ for $20 \mathrm{~min}$ completely abolished the cytotoxicity (Fig. 5). This clearly indicates that the cytotoxin is heat-labile, eliminating the above possibility.

\section{Chemical analysis of the cytotoxin}

It was also possible that low-molecular-mass substances derived from peptidoglycan, such as the tracheal cytotoxin of $B$. pertussis, were responsible for the cytotoxic activity of the purified cytotoxin. Chemical analysis, however, revealed that neither amino acid nor amino sugar was a component of the cytotoxin. In a previous study (Minami et al., 1989), we analysed the cytotoxin purified by HPLC and tentatively estimated its molecular mass to be at most $651 \mathrm{Da}$ on the basis of mass spectroscopy results. However, this preparation was not suitable for accurate and precise chemical analysis by NMR spectroscopy. In order to remove possible impurities which could not be separated from the cytotoxin by the column chromatography routinely used, the cytotoxin fraction obtained on HPLC was separated into chloroform-soluble and chloroform-insoluble fractions. When the soluble fraction was developed on a silica gel thin layer plate with a solvent system of chloroform

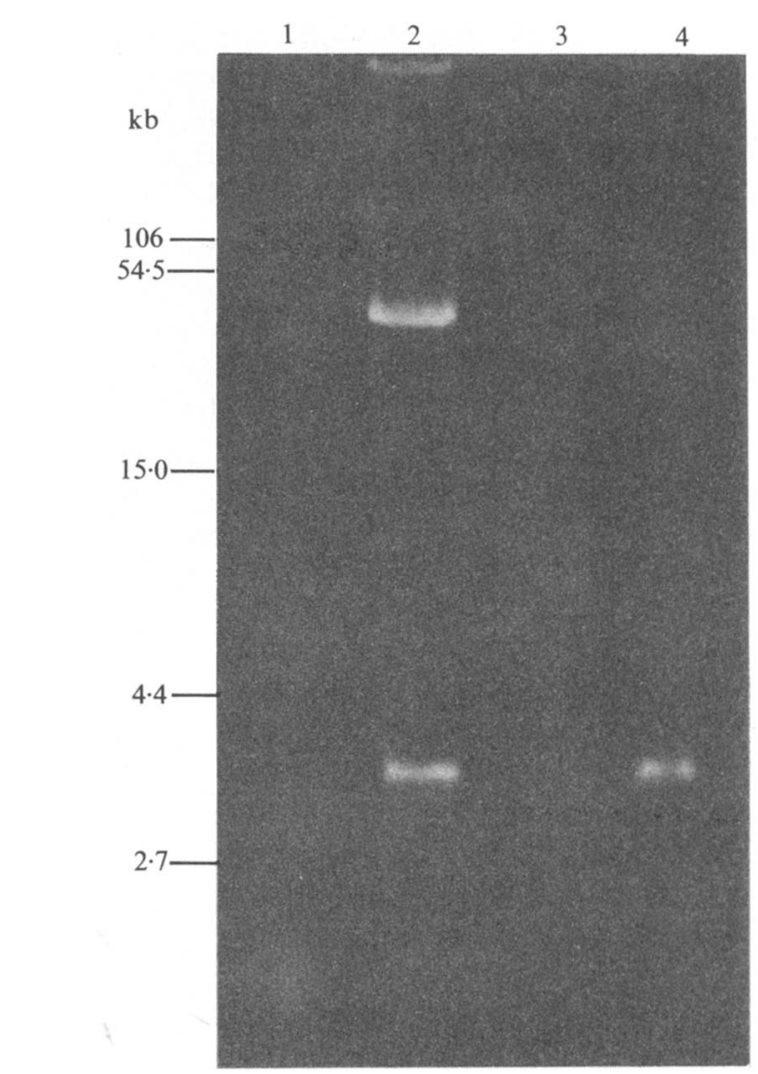

Fig. 4. Analysis of plasmids in $K$. oxytoca strains by agarose gel electrophoresis. Lanes: $1, K$. oxytoca ATCC 13182; $2, K$. oxytoca OK-1; 3, K. oxytoca KA-1; 4, K. oxytoca KA-2. Molecular sizes are indicated on the left side of the gel. Reference plasmids: pUC19 (2.7 kb), pBR322 (4.4 kb), pSK201 (15.0 kb, Katayama et al., 1990), RP4 (54.5 kb), and R100 (106 kb).

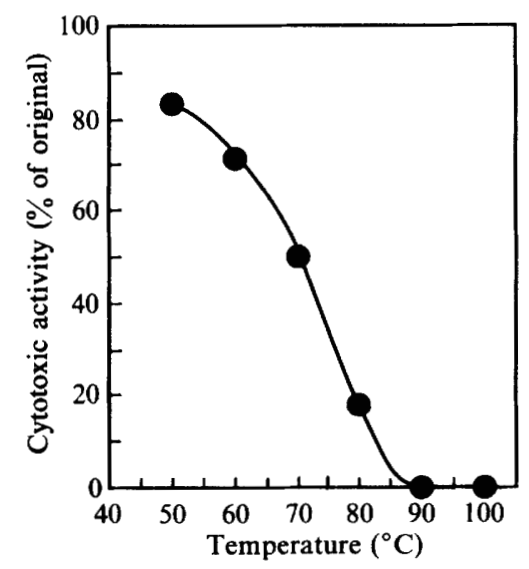

Fig. 5. Heat lability of the $K$. oxytoca cytotoxin. Lyophilized cytotoxin

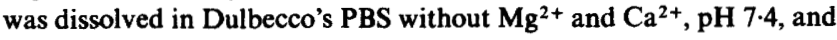
then heated at various temperatures for $20 \mathrm{~min}$. The untreated control had a cytotoxin titre of $20 \mathrm{CD}_{50}$ per well. Cytotoxic activity was measured as described in the text. 
ethanol (24:1), a single spot, of which the $R_{\mathrm{F}}$ value was $0 \cdot 25$, was detected. This soluble fraction showed cytotoxicity toward HEp-2 cells, while the insoluble fraction showed neither cytotoxicity when used alone, nor an additive effect when used together with the soluble fraction. The chloroform-soluble fraction was subjected to NMR and FAB-mass-spectroscopy to gain more insight into the chemical structure and molecular mass of the cytotoxin. Before subjecting the cytotoxin to ${ }^{1} \mathrm{H}$ and ${ }^{13} \mathrm{C}$-NMR spectroscopies, ${ }^{31} \mathrm{P}-\mathrm{NMR}$ analysis was performed to confirm that no phosphorus atoms were present in the cytotoxin. The ${ }^{1} \mathrm{H}-\mathrm{NMR}$ spectrum of the cytotoxin indicated the presence of eleven protons $\left(\mathrm{H}_{11}\right)$, i.e. four olefinic $(4 \times-\mathrm{CH}=)$, three heteroatom-linked aliphatic $\left(\mathrm{CH}+\mathrm{CH}_{2}\right)$, and four normal aliphatic $\left(2 \times \mathrm{CH}_{2}\right)$ and rather intense exchangeable protons. The ${ }^{13} \mathrm{C}-\mathrm{NMR}$ spectrum of the cytotoxin indicated the presence of eight carbons, i.e. three $\mathrm{CH}_{2} \mathrm{~s}$, one $\mathrm{CH}$, and four $=\mathrm{CHs}$. Two-dimensional heteronuclear correlation analysis of the cytotoxin indicated that all of these carbon signals were reasonably correlated with the observed proton signals, except for the exchangeable proton signals, thereby establishing the $\mathrm{C}_{8} \mathrm{H}_{11}$ unit. Thus, at the present time, the number of carbon atoms could be unambiguously determined by NMR, whereas the exact numbers of protons and heteroatoms could not, because of the presence of exchangeable $\mathrm{OH}$ and/or $\mathrm{NH}$ protons. However, the FAB mass spectrum of the cytotoxin indicated that $\mathrm{M}^{+}$was 217 ; six molecular formulae satisfied $m / z=217$, among which only one, $\mathrm{C}_{8} \mathrm{H}_{15} \mathrm{O}_{4} \mathrm{~N}_{3}$ (exact mass $=217 \cdot 1062$ ), contained the eight carbons determined by NMR spectroscopy. The chemical structure of the cytotoxin, therefore, should comprise the combination of $\mathrm{C}_{8} \mathrm{H}_{11}$ and $\mathrm{H}_{4} \mathrm{O}_{4} \mathrm{~N}_{3}$ $\left(=\mathrm{C}_{8} \mathrm{H}_{15} \mathrm{O}_{4} \mathrm{~N}_{3}-\mathrm{C}_{8} \mathrm{H}_{11}\right)$ units, but a final conclusion must await future studies involving, e.g. $\mathrm{X}$-ray crystallographic analysis or chemical synthesis.

\section{Discussion}

Previously, we showed that $K$. oxytoca cytoxin causes cell-rounding of tissue culture cells such as $\mathrm{HEp}-2, \mathrm{CHO}$, $\mathrm{HeLa}$, and Vero cells. The results presented in this paper indicate that cell-rounding is a process leading to celldeath with energy metabolism suppressed. That HEp-2 cells were irreversibly damaged before the manifestation of the morphological change implies that cell metabolism should be critically affected at an early stage. Although energy metabolism and macromolecular synthesis were all inhibited by the cytotoxin, DNA synthesis was inhibited most prominently. Furthermore, inhibition of DNA synthesis occurred in the early period when the irreversibility of the cytotoxicity was established. Therefore, the cytotoxic effect on HEp-2 cells seems to be primarily the consequence of the inhibitory effect of the cytotoxin on DNA synthesis.

The cytotoxin is not produced by $K$. oxytoca type strain ATCC 13182 (Minami et al., 1989), suggesting that a gene encoding enzymes involved in its synthesis might be on a plasmid. In $K$. oxytoca $\mathrm{OK}-1$ there were two plasmids, 34 and $3.5 \mathrm{~kb}$ in size. This strain produced the cytotoxin even after curing of the smaller plasmid by treatment with ethidium bromide. In addition, a plasmid-free strain, KA-1, produced the cytotoxin similarly to the other strains. Therefore, the cytotoxin is probably chromosomally encoded, although it is still uncertain why some strains can but others cannot produce it.

Analysis of the purified cytotoxin by NMR and FABmass-spectrometry allowed the determination of its molecular mass and formula. The extremely low molecular mass and simple molecular formula of the cytotoxin are unexpected considering the sizes and structures of bacterial cytotoxins reported previously. We speculate that such a low-molecular-mass toxin or related compounds could be produced by many other enteric bacteria, and be responsible for their pathogenicity in the intestinal tract. A further detailed study on the chemical structure of the $K$. oxytoca cytotoxin might be very useful for understanding the pathogenesis of potentially pathogenic bacteria causing opportunistic infections as well as the virulence of $K$. oxytoca. The examination of chemical groups by means of NMR spectroscopy and crystallographic analysis is now in progress.

We wish to thank Dr H. Hayashi (University of Tsukuba, School of Medicine) for his kind encouragement and useful advice, and Dr S. Katayama (Kagawa Medical School) and Dr O. Matsushita (Kagawa Medical School) for their useful discussions, and $\mathrm{Dr} \mathrm{T}$. Konobe and $\mathrm{Dr}$ I. Yoshida (Kanonji Institute, The Research Foundation for Microbial Diseases of Osaka University) for their advice as to the purification of the $K$. oxytoca cytotoxin. We also thank Mr A. Miyatake (Research Equipment Center, Kagawa Medical School) for his technical assistance in ATP assay and the SC-NMR Laboratory of Okayama University for the high field NMR experiments.

\section{References}

Ashrenazi, S., Cleary, T. G., Murray, B. E., Wanger, A. \& PICKERING, L. K. (1988). Quantitative analysis and partial characterization of cytotoxin production by Salmonella strains. Infection and Immunity 56, 3089-3094.

Baloda, S. B., Faris, A., Krovacek, K. \& Wadstrom, T. (1983). Cytotoxic enterotoxins and cytotoxic factors produced by $S$. enteritidis and S. typhimurium. Toxicon 21, 785-790.

Cookson, B. T., Cho, H.-L., Herwaldt, L. A. \& Goldman, W. E. (1989). Biological activities and chemical composition of purified tracheal cytotoxin of Bordetella pertussis. Infection and Immunity 57, 2223-2229

Donta, S. T. \& Shaffer, S. J. (1980). Effects of Clostridium difficile toxin on tissue-cultured cells. Journal of Infectious Diseases 141, 218 222 . 
Guerrant, R. L., Wanke, C. A., Pennie, R. A., Barrett, L. J., Lima, A. A. M. \& O'Brien, A. D. (1987). Production of a unique cytotoxin by Campylobacter jejuni. Infection and Immunity 55, 2526-2530.

KADO, C. I. \& LIU, S.-T. (1981). Rapid procedure for detection and isolation of large and small plasmids. Journal of Bacteriology 145, 1365-1373

Katayama, S., Ninomiya, M., Minami, J., OKabe, A. \& Hayashi, H. (1990). Transcriptional control plays an important role for the production of heat-labile enterotoxin in enterotoxigenic Escherichia coli of human origin. Microbiology and Immunology 34, 11-24.

Ketyi, I., Pacsa, S., Emody, L., Vertenyi, A., Kocsis, B. \& Kuch, B. (1979). Shigella dysenteriae l-like cytotoxic enterotoxins produced by Salmonella strains. Acta Microbiologica Hungarica 26, 217-223.

Koo, F. C. W. \& Peterson, J. W. (1983). Cell-free extracts of Salmonella inhibit protein synthesis and cause cytotoxity in eukaryotic cells, Toxicon 21, 309-320.

Lima, A. A. M., Lyerly, D. M., Wilkins, T. D., INNES, D. J. \& GUERRANT, R. L. (1988). Effects of Clostridium difficile toxins A and
$B$ in rabbit small and large intestine in vivo and on cultured cells in vitro. Infection and Immunity 56, 582-588.

Minami, J., OKabe, A., Shiode, J. \& Hayashi, H. (1989). Production of a unique cytotoxin by Klebsiella oxytoca. Microbial Pathogenesis 7, 203-211.

O'Brien, A. D. \& Holmes, R. K. (1987). Shiga and Shiga-like toxins. Microbiological Reviews 51, 206-220.

O'Brien, A. D., La Beck, G. D., Thompson, M. R. \& Formal, S. B. (1982). Production of Shigella dysenteriae type 1-like cytotoxin by Escherichia coli. Journal of Infectious Diseases 146, 763-769.

Rosenthal, R. S., Nogami, W., CoOkson, B. T., Goldman, W. E. \& FoLKENING, W. J. (1987). Major fragment of soluble peptidoglycan released from growing Bordetella pertussis is tracheal cytotoxin. Infection and Immunity 55, 2117-2120.

Watanabe, F., Hashimoto, T. \& Tagawa, K. (1985). Energyindependent protection of the oxidative phosphorylation capacity of mitochondria against anoxic damage by ATP and its nonmetabolizable analogs. Journal of Biochemistry 97, 1229-1234. 